\title{
Organic waste removal from pharmaceutical and textile effluents using composite adsorbent
}

\author{
M. Khatun ${ }^{1,2}$, G. Mohammad $^{2}$, Mir T. $\operatorname{Rahman}^{1}$ and S. E. Kabir ${ }^{1 *}$ \\ ${ }^{1}$ Department of Chemistry, Jahangirnagar University, Savar, Dhaka 1342 \\ ${ }^{2}$ Gonoshasthaya Pharmaceuticals, Mirzanagar, Savar, Dhaka 1344
}

Received: 15 December 2019

Revised: 21 January 2020

Accepted: 08 July 2020

DOI: 10.3329/bjsir.v55i3.49393

\begin{abstract}
Pharmaceutical and textile industries widely use inorganic and organic components which undergo different chemical and biochemical reactions with the ground water systems. The removal of organic wastes from effluents was carried out using a composite adsorbent. Four different samples were collected from the Gonoshasthaya Antibiotic Limted, Gonoshasthaya Pharmaceuticals Limited, Pakiza Dyeing and Printing Industries Limited and Bangladesh Dyeing and Finishing Industries Limited. Synthetic effluents of four types were prepared maintaining a similar chemical average of the collected samples. All the samples contained a high concentration of TDS, TSS, TS, COD and $\mathrm{BOD}_{5}$. The composite adsorbent performed excellently for all the samples. The concentrations of the components contained in the waste water were analyzed by UV-Visible spectrophotometer and High Performance Liquid Chromatography (HPLC). After the treatment, the decreasing trend of the absorbance and total peak area indicated that the significant amount of effluent materials were removed.
\end{abstract}

Keywords: Organic wastes; Composite adsorbent; BOD; COD; DO

\section{Introduction}

Pharmaceutical and textile industries in Bangladesh are widely distributed throughout the country and there is a consistent global increase in the use and production of potent pharmaceutical, distribution of yarn, cloth and clothing respectively (Aust et al., 1990). These industries use both inorganic and organic compounds as raw materials, latter being either of synthetic or of vegetable and animal origin (Rao and Datta, 1979). The inorganic compounds are mainly metallic salts and various other basic and acidic compounds that undergo different chemical and biochemical reactions in the water systems (Safiullah et al., 1989). The organic compounds can be of biodegradable and non-biodegradable in nature. The biodegradable organic component through its degradation creates several hazardous situations in the water system, such as depletion of dissolved oxygen (DO), production of odorous gases, change of $\mathrm{pH}$ etc. The non-biodegradable organic substances persist in the water system for a long time and passes through the food chain (Khan, 2010). The pharmaceutical and textile industries have been playing a significant role in Bangladesh's economical growth for a long time. Currently, the textile industries in Bangladesh contributes $5 \%$ of the total national income (Mandal, 2013) and 46.98\% gross outputs of top ten industrial sectors in Bangladesh (Sagris and Abbott, 2015). On the other hand, Bangladesh is the only least developed country in the world that meets up to $97 \%$ of its demand for pharmaceutical products through local companies (Mahmud, 2018). Among these industries, some do not discharge liquid waste at all, while some discharge concentrated liquid waste in very small scale. Most of other industries discharge highly alkaline and toxic liquid wastes. The discharged effluent contains high BOD, COD, dissolved and suspended matters, heavy metals, dye compounds (Sagris and Abbott, 2015; SWIG-Textile, 1997). 
In order to prevent environmental pollution, there have been different methods to treat the waste water and reuse it. The ancient methods employed for the treatment of waste water includes physical, chemical and thermal methods. But these methods have disadvantages which includes huge labor requirement, high maintenance cost, low efficiency and large equipment. Adsorption technique has attracted a great amount of attention due to its cost effectiveness, easy operation, high efficiency, simplicity of the equipment, and easy regeneration of materials (Shan et al., 2015). Activated charcoal is a form of carbon that is extremely porous and have a very large surface area available for adsorption and chemical reactions. Adsorption on activated carbon is selective, favoring non polar over polar substances (Ashraf et al., 2019; Yagub et al., 2014; Sun et al., 2013). In this study, our objective was to modify the activated charcoal by manganese dioxide, ferric oxide, soil, sand and make a composite to improve the adsorption capacity and versatility.

\section{Materials and methods}

\section{Preparation of composite adsorbent}

A $100 \mathrm{~g}$ composite material was prepared by mixing of $10 \%$ activated charcoal (Source - BDH Chemicals Ltd. England, granular size 10-18 mesh), 10\% manganese dioxide (Source - BDH Chemicals Ltd. England), 20\% ferric oxide (Source Qualikems Fine Chemicals Pvt. Ltd. India), 40 \% soil (Source - Jahangirnagar University, Bangladesh, granular size 10-15 mesh) and 20\% sand (Source - Padma River, Pakshi, Kushtia, Bangladesh, granular size 250-355 $\mu \mathrm{m}$ ). Following the uniform mixing, it was dried at $105{ }^{\circ} \mathrm{C}$ for two hours and kept in a desiccator to avoid the gaining of moisture. Then, the content of composite materials was taken in a column made up of glass tube having an internal diameter $22 \mathrm{~mm}$ and height of content $270 \mathrm{~mm}$.

\section{Sample collection}

Four different types of samples were collected from the discharge points of Gonoshasthaya Antibiotic Limted, Mirzanagar, Dhaka (GAL); Gonoshasthaya Pharmaceuticals Limited, Mirzanagar, Dhaka (GPL); Pakiza Dyeing and Printing Industries Ltd., Choto Bali Mehor, Savar, Dhaka (PDPI) and Bangladesh Dyeing and Finishing Ind. Ltd., DOEL group, Karanpara, Savar, Dhaka (BDFI). 2.01 of the effluent liquid samples were collected from each sampling location approximately $500 \mathrm{~cm}$ depth from the surface of the water to avoid the contamination from any floating materials. The standard water sampler (Hydro Bios, Germany) was used with four pre-cleaned $500 \mathrm{ml}$ plastic containers to collect the water from each sampling site. Then waters from four containers $(4 \times 500 \mathrm{ml}=2 \mathrm{l})$ were mixed together to obtain a mixture. The effluent mixture was filtered through $0.45 \mu \mathrm{m}$ membrane filters.

\section{Preparation of synthetic effluents}

Four synthetic effluents were prepared which represent an average character of the samples collected from GAL, GPL, PDPI and BDFI sampling locations. The synthetic effluents were marked as GAL-SYN, GPL-SYN, PDPI-SYN and BDFI-SYN respectively.

\section{Preparation of GAL-SYN}

$2.0 \mathrm{~g}$ each of the materials such as methylene chloride, isopropyl alcohol, 2,6-lutidine, 2-ethylhexanoic acid, hydrochloric acid, N, N-dimethylacetamide, triethylamine, acetone, ethyl acetate, ethanol, methyl isobutyl ketone, n-butanol and methanol were diluted to $200 \mathrm{ml}$ with distilled water. This solution was termed as 'Solution $-A$ '. 'Solution $B$ ' was prepared by dissolving 6-aminopenicillanic acid $(0.2052 \mathrm{~g})$, ethylene diamine tetraacetic acid (0.2026 g), charcoal $(0.2010 \mathrm{~g})$, sodium chloride $(0.2006 \mathrm{~g})$, sodium sulfate $(0.2002 \mathrm{~g})$, amoxicillin trihydrate $(0.2049 \mathrm{~g})$, flucloxacillin sodium $(0.2037 \mathrm{~g})$, cefradine $(0.2040 \mathrm{~g})$, cloxacillin sodium $(0.2094 \mathrm{~g})$, ciprofloxacin hydrochloride $(0.2020 \mathrm{~g}), 3$-(2-chloro- 6-fluorophenyl)- 5-methyl isoxazole4-carbonyl chloride $(0.2025 \mathrm{~g}), \mathrm{D}(-)$ alpha para hydroxyl phenyl glycine methyl potassium $(0.2052 \mathrm{~g})$ in $2000 \mathrm{ml}$ distilled water. Then, $10 \mathrm{ml}$ of Solution $-A$ and $90 \mathrm{ml}$ of Solution $-B$ were mixed and diluted to $200 \mathrm{ml}$ by distilled water. Again, $40 \mathrm{ml}$ of this solution was diluted to $1000 \mathrm{ml}$ using distilled water.

\section{Preparation of GPL-SYN}

GPL-SYN solution was prepared by dissolving amoxicillin sodium $(0.210 \mathrm{~g})$, chlorphenamine maleate $(0.202 \mathrm{~g})$, atropine sulfate $(0.206 \mathrm{~g})$, amlodipine besilate $(0.242 \mathrm{~g})$, atorvastatin as calcium $(0.205 \mathrm{~g})$, bupivacaine hydrochloride $(0.211 \mathrm{~g})$, chloramphenicol $(0.203 \mathrm{~g})$, trimethoprime $(0.201$ $\mathrm{g})$, calcium gluconate $(0.207 \mathrm{~g})$, ciprofloxacin lactate $(0.205$ $\mathrm{g})$, cefixime $(0.202 \mathrm{~g})$, diazepam $(0.204 \mathrm{~g})$, diclofenac sodium $(0.202 \mathrm{~g})$, dexamethasone sodium phosphate $(0.205 \mathrm{~g})$, furosemide $(0.207 \mathrm{~g})$, flucloxacillin sodium $(0.207 \mathrm{~g})$, griseofulvin (0.2022 g), haloperidol $(0.208 \mathrm{~g})$, methylparaben $(0.204 \mathrm{~g})$, providone $(0.2075 \mathrm{~g})$, magnesium stearate $(0.204$ $\mathrm{g})$, sodium saccharin $(0.109 \mathrm{~g})$, folic acid $(0.025 \mathrm{~g})$, ketamine hydrochloride $(0.203 \mathrm{~g})$, lidocanine hydrochloride $(0.208 \mathrm{~g})$, metronidazole $(0.209 \mathrm{~g})$, misoprostol $1 \% \quad(0.206 \mathrm{~g})$, metformin hydrochloride (0.204 g), neostigmine methyl sulfate $(0.205 \mathrm{~g})$, paracetamol $(0.200 \mathrm{~g})$, phenobarbital 
sodium (0.201 g), prednisolone (0.205 g), salbutamol sulfate $(0.2073 \mathrm{~g})$, hydrochlorothiazide $(0.203 \mathrm{~g})$, thiamine hydrochloride $(0.207 \mathrm{~g})$, riboflavin $(0.010 \mathrm{~g})$, maize starch $(0.210 \mathrm{~g})$ and lactose $(0.192 \mathrm{~g})$ in $2000 \mathrm{ml}$ distilled water. Then $28 \mathrm{ml}$ of this solution was diluted to $1000 \mathrm{ml}$ using distilled water.

\section{Preparation of PDPI-SYN}

$1.0 \mathrm{~g}$ each of the materials sodium bicarbonate, urea, soda ash, sodium chlorate, resis salt, alginate gum and $10.0 \mathrm{~g}$ each of the silicon softener (liquid), detergent (liquid), acetic acid (10\%), sodium hydroxide (10\%) were dissolved in $100 \mathrm{ml}$ distilled water. $50 \mathrm{ml}$ of this solution was mixed with $50 \mathrm{ml}$ red BP (reactive), $0.1 \%$ and yellow - H4G (reactive), $0.1 \%$. Then, the solution was diluted to $1000 \mathrm{ml}$ using distilled water.

\section{Preparation of BDFI-SYN}

$10.0 \mathrm{~g}$ each of the materials detergent (liquid), sequestering agent KEB/SED (liquid), anti creasing agent Ciba - C (liquid), peroxide killer (liquid) and $10 \mathrm{ml}$ of each of hydrogen peroxide (10\% solution), sodium hydroxide $(10 \%$ solution), hydrose ( $10 \%$ solution), acetic acid ( $10 \%$ solution), glauber's salt ( $10 \%$ solution), sodium bicarbonate $(10 \%$ solution) were dissolved to $100 \mathrm{ml}$ distilled water. Then, 50 $\mathrm{ml}$ of this solution was mixed with $50 \mathrm{ml}$ reacto bond red $3 \mathrm{BX}$, Kiri, India ( $0.1 \%$ solution) and $50 \mathrm{ml}$ selazol blue BRF, setaschemiya, China ( $0.1 \%$ solution). The solution was then diluted to $1000 \mathrm{ml}$ using distilled water.

Treatment of practical and synthetic effluent by composite adsorbent (column method)

The effluent treatment ability of the composite adsorbent was examined through column method. In this method, a fixed amount of composite material (100 g) was taken in a column made up of glass tube having an internal diameter $22 \mathrm{~mm}$ and height of content $270 \mathrm{~mm}$. The lower end of the column is bent in the form of a burette having a stop cock for controlling out flow. Glass fiber filter is placed at the lower end of the column, first to support the adsorbent and second to allow only liquid to pass through it. A $200 \mathrm{ml}$ effluent from different samples was passed through the column containing the adsorbent. The flow rate was maintained $2.0 \mathrm{ml} /$ minute. The treated water was collected in a plastic container for further analysis.

\section{Analytical method}

The principal equipments used in this study were High Performance Liquid Chromatography (HPLC) (Shimadzu, Japan, model - CTO - 10 AS), LC - 20AT (solvent delivery module), SPD - 20A (uv visible detector); UV-Visible spectrophotometer (Shimadzu, Japan, model - 1601PC). TDS, DO, BOD and COD were analyzed using APHA method (APHA et al., 2017).

\section{Results and discussion}

\section{Physical appearance and $\mathrm{pH}$}

The physical appearance of the samples collected from the GAL and GPL were found yellowish brown with objectionable odor. But a deep reddish brown and deep violet colors were found in the samples collected from PDPI and BDFI respectively. In the textile-dyeing industries, a mixture

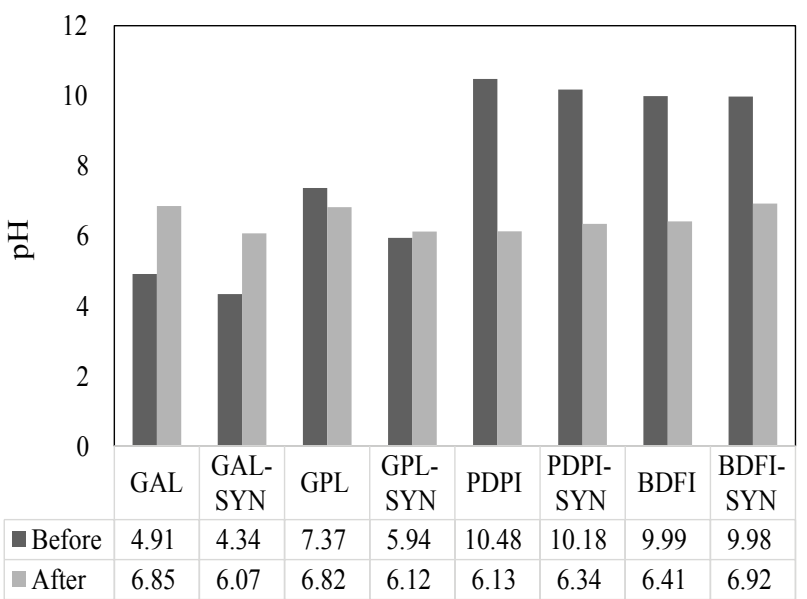

Fig. 1. Change of pH in different samples before and after treatment

of azoic (for example, fast violet $\mathrm{B}$ base, fast violet $\mathrm{K}$ base, fast blue RR base) and vat (for example, algol blue 3R, indenthren yellow 5FK, indigo) dyes were used in the different steps of the production (Khan, 2010). Therefore, a lot of dye containing effluent are released from these industries. In case of synthetic effluent, it was observed that all the samples were clear but different in colors. A colorless, light yellowish, deep red and deep violet blue colors were observed for GAL-SYN, GPL-SYN, PDPI-SYN and BDFI-SYN samples respectively. All the samples (both practical and synthetic) were found clear, colorless and odorless after the treatment with composite adsorbent. A wide range of $\mathrm{pH}$ variation was observed in Fig. 1 for 
different samples. The effluents collected from GAL and GPL, both practical and synthetic were found acidic in nature. These effluents contain a wide variety of chemicals such as acids, drugs, salts etc. $\mathrm{pH}$ values generally depend on the nature of chemicals used in synthesis and other compounds and their reaction mechanism (Satyanarayana et al., 2015). Satyanarayana et al. (2015) observed that the effluents collected from different pharmaceutical industries were commonly acidic in nature. On the other hand, effluents from PDPI and BDFI, both practical and synthetic were alkaline in nature (Fig. 1). The $\mathrm{pH}$ of textile effluent is generally high due to use of many alkaline substances in textile processing
(Islam and Guha, 2013). After the treatment, all samples were well within in the range of the standards established by different organizations (Table I).

\section{Total dissolved solids (TDS)}

Fig. 2 shows that the total dissolved solids in GAL, GPL, PDPI and BDFI were 685, 259, 1890 and $4760 \mathrm{mg} / \mathrm{l}$ respectively and in GAL-SYN, GPL-SYN, PDPI-SYN and BDFI-SYN were 19.9, 76.4, 5712 and $4891 \mathrm{mg} / \mathrm{l}$ respectively. The concentrations were significantly high in textile and dyeing related samples, for example, PDPI, BDFI, PDPI-SYN and

Table I. Water quality standard of physico-chemical parameters from different organizations

\begin{tabular}{|c|c|c|c|c|c|}
\hline \multirow[t]{2}{*}{ Parameter } & \multirow[t]{2}{*}{ Unit } & \multicolumn{2}{|c|}{ DoE, BD } & \multirow{2}{*}{$\begin{array}{c}\text { MoE, JP } \\
\begin{array}{c}\text { National effluent } \\
\text { standard }\end{array}\end{array}$} & \multirow{2}{*}{$\begin{array}{c}\text { EPA } \\
\begin{array}{l}\text { Surface } \\
\text { water }\end{array}\end{array}$} \\
\hline & & $\begin{array}{l}\text { Inland surface } \\
\text { water }\end{array}$ & Irrigatedl and & & \\
\hline $\mathrm{pH}$ & & $6-9$ & $6-9$ & $5.8-8.6$ & $5.5-9.0$ \\
\hline TDS & $\mathrm{mg} / \mathrm{l}$ & 2100 & 2100 & & \\
\hline TSS & $\mathrm{mg} / 1$ & 150 & 200 & 200 & 50 \\
\hline $\mathrm{BOD}_{5}, 20^{\circ} \mathrm{C}$ & $\mathrm{mg} / \mathrm{l}$ & 50 & 100 & 160 & 5 \\
\hline COD & $\mathrm{mg} / \mathrm{l}$ & 200 & 400 & 160 & 40 \\
\hline DO & $\mathrm{mg} / \mathrm{l}$ & $4.5-8$ & $4.5-8$ & & \\
\hline
\end{tabular}

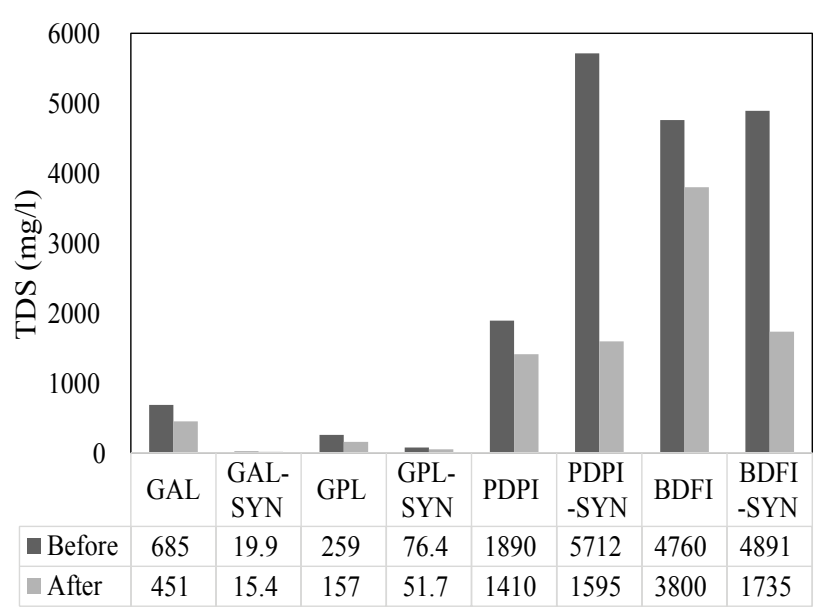

Fig. 2. Concentration of TDS in different samples before and after treatment
BDFI-SYN. The composite adsorbent performed in removing the dissolved solids $20-40 \%$ for the samples. But, the samples PDPI-SYN and BDFI-SYN showed a higher removal of $65-2 \%$. The total dissolved solids comprise inorganic salts and some small amount of organic matters which are dissolved in water. In case of inorganic salt, the principal components present as cations are: calcium, magnesium, sodium and potassium, while for anions are: carbonate, bicarbonate, chloride, sulfate and nitrate (DNHW 1993). Beside these, a wide variety of organic and inorganic components are present in the practical waste water. Some of these are complex in nature, especially in the different types of bond formation. This might be the reason for lower removal in the practical effluent than the synthetic. According to the guideline of DoE, BD (Table I), the permissible limit of TDS is $2100 \mathrm{mg} / \mathrm{l}$ for both inland 


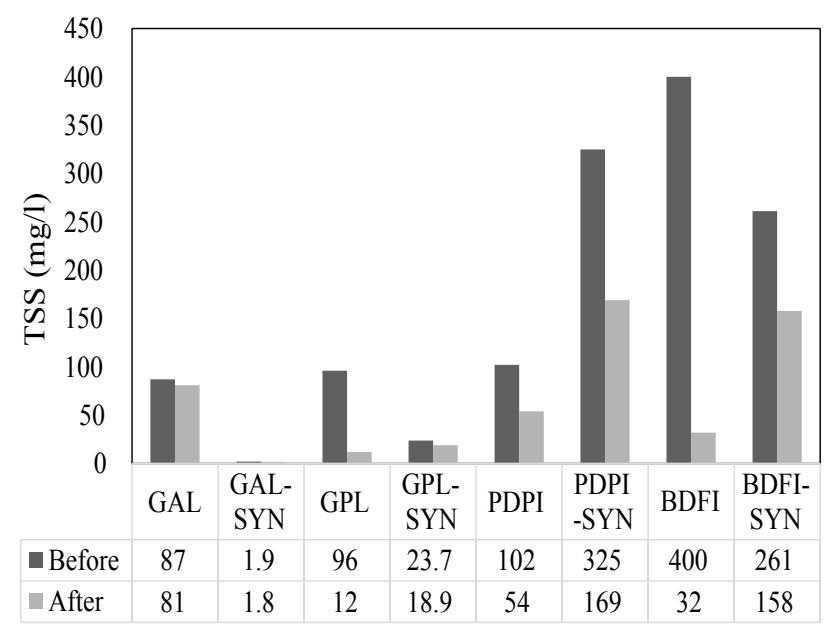

Fig. 3. Concentration of TSS in different samples before and after treatment

surface water and irrigated land. After the treatment, it is observed that the concentration of TDS in all the samples are within the limit, except BDFI sample.

\section{Total suspended solids (TSS)}

Fig. 3 shows that the total suspended solids in GAL, GPL, PDPI and BDFI were 87, 96, 102 and $400 \mathrm{mg} / \mathrm{l}$ respectively and in GAL-SYN, GPL-SYN, PDPI-SYN and BDFI-SYN were 1.9, 23.7, 325 and $261 \mathrm{mg} / 1$ respectively. According to the guideline of DoE, BD and MoE, JP (Table I), the permissible limit of TSS is $200 \mathrm{mg} / \mathrm{l}$ for both irrigated land and national effluents. After the treatment with composite adsorbent, it is observed that the concentrations of TSS in all the samples are within the limit. TSS are solids in water that can be trapped by filtration. High concentrations of suspended solids can cause many problems for stream and health of aquatic life. It causes to, reduce the photosynthesis and thus the water plants are not capable to produce the oxygen, therefore, decaying occurs. High TSS can also cause an increase in surface water temperature, because the suspended particles absorb heat from the sunlight (Mohammad, 2003).

\section{Chemical oxygen demand (COD)}

The chemical oxygen demand of the samples collected from GAL, GPL, PDPI and BDFI was 1590, 38.4, 585.6 and 192 $\mathrm{mg} / \mathrm{l}$ respectively, whereas, the synthetic waste water contained the COD of 134.4, 590.4, 2428 and $3043 \mathrm{mg} / 1$ for the samples GAL-SYN, GPL-SYN, PDPI-SYN and BDFI-SYN respectively (Fig. 4). From Fig. 4, it is clearly observed that the removal of COD was more than $85 \%$ for the synthetic waste water, but different removals were found for the practical waste water. On the other hand, a high removal was observed from the high concentration of COD containing waste water. Chemical oxygen demand (COD) is the total amount of oxidizable organics (biodegradable and nonbiodegradable and both dissolved and particulate), measured by the amount of oxygen in the

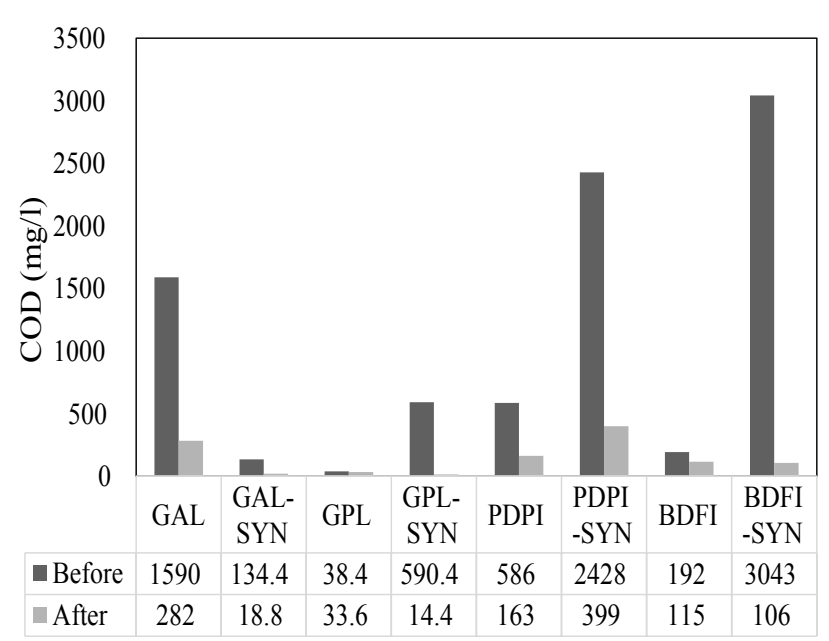

Fig. 4. Concentration of COD in different samples before and after treatment

form of oxidizing agent required for the oxidation of organic matters (Bergem et al., 2018). Table I explains that the permissible limit for the COD in the inland surface water and irrigated land were set 200 and $400 \mathrm{mg} / 1$ according to the DoE, BD. Our treatment experiment shows that most of the samples followed inland surface water standard, whereas, GAL and PDPI-SYN followed irrigated land standard.

\section{Biochemical oxygen demand (BOD)}

The biochemical oxygen demand (5-days, $20 \quad{ }^{\circ} \mathrm{C}$ incubation) of the samples collected from GAL, GPL, PDPI and BDFI was 1280, 2.3, 110 and $24 \mathrm{mg} / \mathrm{l}$ respectively, whereas, the synthetic waste water contained the BOD (5-days, $20^{\circ} \mathrm{C}$ ) of $120,330,1467$ and $400 \mathrm{mg} / \mathrm{l}$ for the samples GAL-SYN, GPL-SYN, PDPI-SYN and BDFI-SYN respectively (Fig. 5). After treatment with composite adsorbent, it was found that the removal was 
more than $80 \%$ in most of the samples. The maximum permissible limit for BOD $\left(5\right.$-days, $\left.20^{\circ} \mathrm{C}\right)$ is $100 \mathrm{mg} / \mathrm{l}$ for the irrigated land by DoE, BD (Table I). After treatment, the samples of GAL, PDPI-SYN and BDFI-SYN contained $\mathrm{BOD}_{5}$ higher than the permissible limit due to high initial concentration. Nevertheless, the removal was observed more than $80 \%$ for these samples. BOD $_{5}$ indicates the amount of putrescible organic matter present in water. Therefore, a high $\mathrm{BOD}_{5}$ indicates polluted water. Dissolved oxygen (DO) is consumed by bacteria when large amounts of organic matter from sewage or other discharges is present in the water.

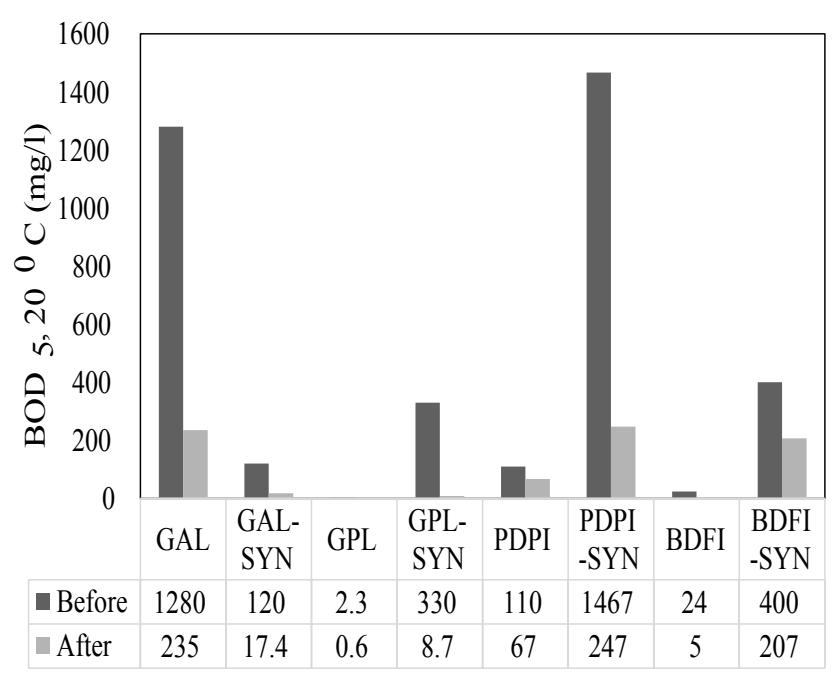

Fig. 5. Concentration of $\mathrm{BOD}_{5}$ in different samples before and after treatment

\section{Dissolved oxygen (DO)}

Fig. 6 shows that the DO values were very low initially. But after the treatment, the DO value increased and contained within the range set by the DoE, BD (Table I). The values in PDPI-SYN and BDFI-SYN still low. Actually, the DO in water is very related with BOD. In these samples, the BOD values were very high, therefore, the demand for oxygen by the bacteria was high and they were taking that oxygen from the oxygen dissolved in the water. When the DO drops below a certain level, the life forms in that water are unable to continue at a normal rate. The decrease in the oxygen supply in the water has a negative effect on the fish and other aquatic life.

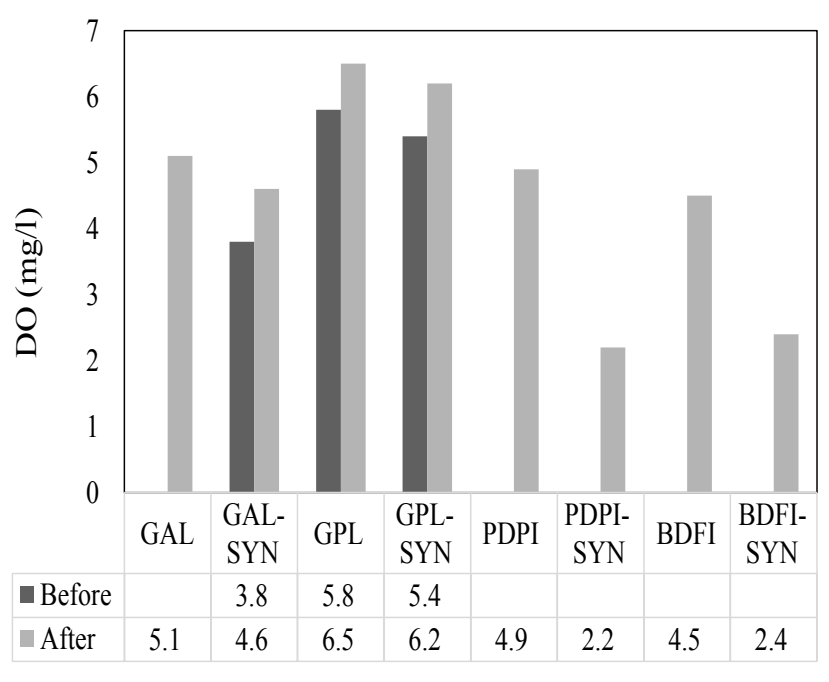

Fig. 6. Concentration of DO in different samples before and after treatment

Total concentration of the substances in the waste water

The concentration of different components contained in the waste water was analyzed by UV-Visible spectrophotometer and High Performance Liquid Chromatography (HPLC). The samples employed in this study contained various types of pharmaceuticals and textile related components. All or most of the components response to spectrophotometric absorbance and HPLC chromatogram. Table II shows that all the samples exhibits absorption peak at different wavelengths. For example, the sample GAL exhibits absorbance 1.2831 and 1.5939 at the wavelengths of 302.5 and $271 \mathrm{~nm}$ respectively. But after the treatment with composite adsorbent, it is clearly observed that the absorbance peaks were reduced or disappeared for all the samples. In case of HPLC analysis, the samples displayed different peak area for different components present in the samples. Table III summarizes the total peak areas for each of the samples. The total peak areas in GAL, GAL-SYN, GPL, GPL-SYN, PDPI, PDPI-SYN, BDFI and BDFI-SYN were observed 1210278, 650574, 249470, 599737, 4305432, 339371, 743910 and $11633041 \mathrm{mV}$-min respectively, whereas after the treatment the values of the total peak areas were reduced to $52510,230243,46354,58924,79725,130915$, 225909 and $222161 \mathrm{mV}$-min respectively. The UV-Vis absorbance and HPLC total peak areas represent the total 
Table II. Spectrophotometric data of different industrial effluents before and after treatment

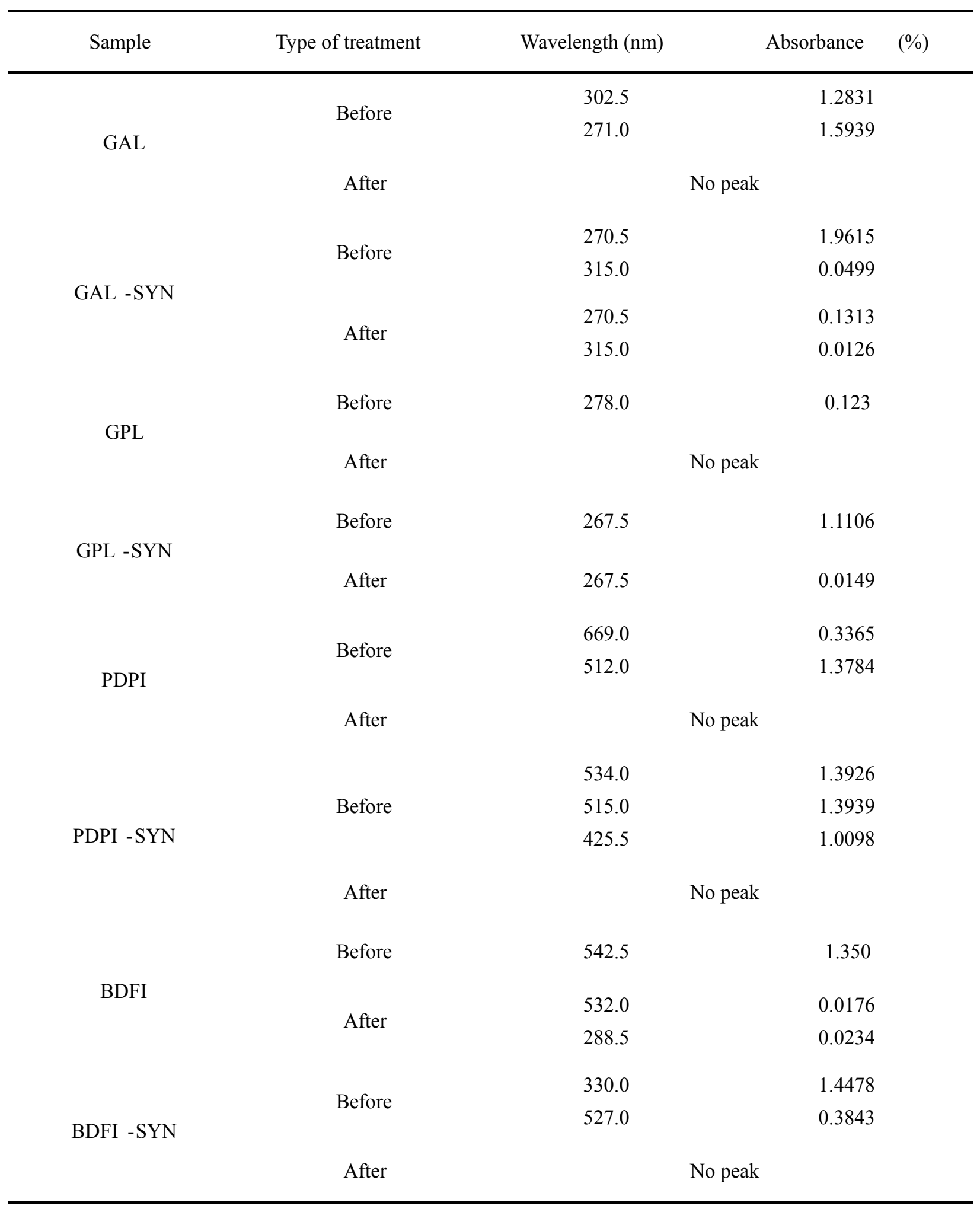


Table III. The total peak area (HPLC analysis) of different industrial effluents before and after treatment

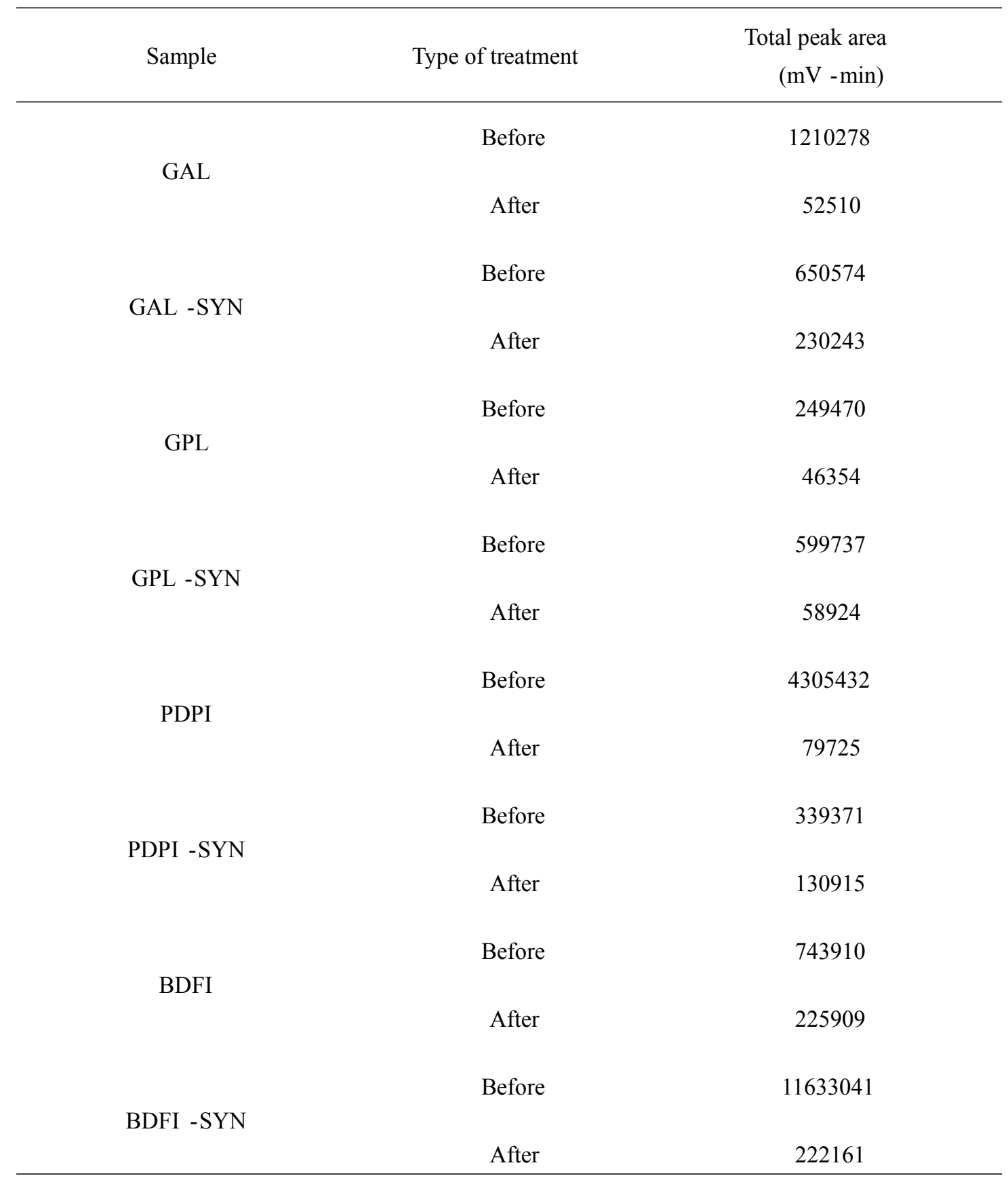


components present in the samples. Therefore, the decreasing trend of the absorbance and total peak area indicated that the significant amount of effluent materials were removed.

\section{Conclusion}

The removal of organic wastes from effluent of pharmaceuticals and textile industries was carried out using a composite adsorbent. Four different types of samples were collected from the discharge points of Gonoshasthaya Antibiotic Limted, Gonoshasthaya Pharmaceuticals Limited, Pakiza Dyeing and Printing Industries Limited and Bangladesh Dyeing and Finishing Industries Limited. Four synthetic effluents were prepared which represen the average character of the collected samples. All the samples contained a high concentration of TDS, TSS, TS, COD and $\mathrm{BOD}_{5}$ with a low value of DO. The composite adsorbent showed excellent treatment capacity for all the samples. The results of UV-Visible and HPLC analysis showed high absorbance and an increase in total peak areas respectively representing considerable amount of components present in the untreated samples. After the treatment with composite adsorbent, it is clearly observed that the absorbance peaks were reduced or disappeared for all the samples. The decreasing trend of the absorbance and total peak area indicated that the significant amount of effluents materials were removed. The findings of this study are important for assessing water purification technologies. Moreover, this work addresses our further understanding of the mechanisms behind the removal processes.

\section{Referrences}

APHA (American Public Health Association) (2017) Standard Methods of Water and Waste Water Analysis, $23^{\text {rd }}$ Ed., New York.

Ashraf MW, Abulibdeh N and Salam A (2019), Adsorption Studies of Textile Dye (Chrysoidine) from Aqueous Solutions Using Activated Sawdust, Int. J. Chem. Eng, Article ID 9728156, DOI: org/10.1155/2019/9728156

Aust SD (1990), Degradation of environmental pollutants by Phanerochaetechrysosporium, Microb. Ecol. 20: $197-$ 209
Bergem H, Biller P, Castello D, Chen WT, Guerrero JKR, Heeres HJ, Ho D, Iversen SB, Jensen CU, Karatzos S, Lødeng R, Nazari L, Olofsson G, Pattiya A, Ray MB, Rosendahl L, Santoro D, Sarathy S and Zhang Y (2018), Direct Thermochemical Liquefaction for Energy Applications, Woodhead Publishing.

DNHW (Department of National Health and Welfare) (1993), Water treatment principle and application: A manual for production of drinking water, Canadian water and waste water association.

Islam A and Guha AK (2013), Removal of pH, TDS and color from textile effluent by using coagulants and aquatic/non aquatic plants as adsorbents, Resources and Environment 3(5): 101-114

Khan MRR (2010), PhD thesis, Department of Chemistry, Jahangirnagar University, Savar, Dhaka, Bangladesh

Mahmud N (2018) Bangladesh's burgeoning pharmaceutical sector: Ruling local market, stock business, and expanding abroad, Dhaka Tribune, (https:/www.dhakatribune.com/business/stock/2018/1 $1 / 03)$

Mandal MJ (2013), An Overview of the Chemical Sector in Bangladesh, (https:// textile learner. blogspot.c om/2013/02)

Mohammad G (2003), PhD Thesis, Jahangirnagar University, Savar, Dhaka, Bangladesh.

Rao MN and Datta AK (1979), Waste Water Treatment, Oxford and IBH publishing Co. Pvt. Ltd., $2^{\text {nd }}$ Ed., New Delhi, 319-324

Safiullah S (1989), Science, Environment and Disaster, pp 49-70. DOI: org/10.15294/jpii.v7i2.14273

Sagris T and Abbott J (2015), An analysis of industrial water use in Bangladesh with a focus on the textile and leather industries, WRG Bangladesh report (https://www.2030wrg.org/wp-content/uploads/2016/0 2/WRG-Bangladesh-Report.pdf)

Satyanarayana SV, Ramamohan RK and Natiq J (2015), Pharmaceutical waste water treatment using hydrogen peroxide oxidation method, Inter. J. Appl. Res., 1(6): 290-293 
Shan R, Yan L, Yang K, Hao Y and Du B (2015), Adsorption of $\mathrm{Cd}$ (II) by $\mathrm{Mg}-\mathrm{Al}-\mathrm{CO}_{3}$ and magnetic $\mathrm{Fe}_{3} \mathrm{O}_{4} / \mathrm{Mg}-\mathrm{Al}-\mathrm{CO}_{3}$ layered double hydroxides: kinetic, isothermal, thermodynamic and mechanistic studies, $J$ Hazard Mater 299: 42-49. DOI: org/10.1016/j.jhazmat.2015.06.003

Sun D, Zhang Z, Wang M and Wu Y (2013), Adsorption of reactive dyes on activated carbon developed from enteromorphaprolifera, Am. J. Anal. Chem. 4: 17-26. DOI: 10.4236/ajac.2013.47A003

SWIG (Sector Wise Industrial Guidelines)-Textile (1997), Department of Environment, Ministry of Environment and Forest, Government of the
People's Republic of Bangladesh, Prepared by Resource Control Company, Bangladesh, AIC Watson Consultants Ltd. India, Planning and Development Services Ltd., Bangladesh, pp 14 -16

Yagub MT, Sen TK, Afroze S and Ang HM (2014), Dye and its removal from aqueous solution by adsorption: A review, Adv Colloid Interfac 209: 172-184. DOI: org/10.1016/j.cis.2014.04.002 